\title{
Subcapsular and Perirenal Hematoma after Ureteroscopy and Pneumatic Lithotripsy
}

\author{
Mustafa Resorlu, Murat Tolga Gulpinar, Gurhan Adam
}

Canakkale Onsekiz Mart University, Canakkale, Turkey

Correspondence: $\mathrm{M}$. Resorlu, Canakkale Onsekiz Mart University, Radiology

Kepez, Canakkale, 17100, Turkey

E-mail: mustafaresorlu77@gmail. com

Tel.: +905054548722

Received: 5 Dec 2016

Accepted: 20 June 2016

Published Online: 8 Aug 2016

Published: 30 Sep 2016

Key words: subcapsular hemato$\mathrm{ma}$, ureteral stone, ureteroscopy

Citation: Resorlu M, Sulpinar MT, Adam G. Subcapsular and Perirenal Hematoma after Ureteroscopy and Pneumatic Lithotripsy.

Folia Medica 2016;58(3);215-217,

doi: 10.1515/folmed-2016-0030
Subcapsular or perirenal hematoma is an unusual complication after semirigid ureteroscopy using pneumatic lithotripsy to treat ureteral stones. We present a patient who developed a large subcapsular and perirenal hematoma following ureteroscopy administered to a stone in the right ureter.

\section{INTRODUCTION}

Ureteroscopic treatment of ureteral stones is an effective option with high success and low complication rates. ${ }^{1,2}$ Pneumatic lithotripters are the most popular lithotripsy devices worldwide due to their safety and effectiveness. ${ }^{3}$ Subcapsular or perirenal hematoma is an unusual complication after ureteroscopy (URS) using pneumatic lithotripsy to treat ureteral stones. This complication can be classified as Grade 2b complication according to Satava classification system. ${ }^{4}$ To our knowledge, there has been only one detailed case reported by Bansal et al..$^{5}$ In the present study we summarized our case of subcapsular and perirenal hematoma following semirigid URS with pneumatic lithotripsy.

\section{MATERIAL AND METHODS}

A 48-year-old man with a history of diabetes mellitus presented to our clinic with right flank pain and hematuria. Non-contrast computed tomography (CT) scan showed a 10-mm stone in the right distal ureter with moderate dilatation of pelvicalyceal system (Fig. 1A).

URS procedure was performed with a semirigid ureteroscope $(7.5 \mathrm{Fr})$ under general anesthesia. A 0.035 inch guidewire was inserted into the ureteral orifice to facilitate passage of the ureteroscope. Ballon dilation was not required. The stone was visualized in distal ureter and fragmented with a pneumatic lithotripter until it was deemed small enough to pass spontaneously. A 6-Fr 26-cm double$J$ stent was placed at the end of the procedure.

\section{RESULTS}

Twenty hours after operation the patient reported severe right flank pain. Right kidney was painful on palpation. He had fever $\left(39^{\circ} \mathrm{C}\right)$ and elevated blood pressure $(160 / 100 \mathrm{~mm} \mathrm{Hg})$. Because of these findings we did an abdominal CT scan. The CT scan showed a 12-by-10-cm subcapsular and perirenal hematoma of right kidney (Fig. $1 \mathbf{B}$ ).

The patient received conservative therapy with observation and serial hematocrits. Hemoglobin levels were stable and never under $10 \mathrm{~g} / \mathrm{dL}$. However, over the 72 hours that followed, the patient 
continued to have persistent abdominal pain and high fever, so we decided to operate. A 8 Fr percutaneous drainage catheter was inserted into the hematoma under US guidance. His symptoms gradually improved after drainage, and he was discharged uneventfully. In the following period, the perirenal hematoma progressively resolved without evidence of renal atrophy (Fig. $1 C$ ). tripsy for treating large proximal ureteral stones. J Urol 2004; 172:1899-902.

3. Gonen M, Cenker A, Istanbulluoglu O, et al. Efficacy of dretler stone cone in the treatment of ureteral stones with pneumatic lithotripsy. Urol Int 2006;76:159-62.

4. Tepeler A, Resorlu B, Sahin T, et al. Categorization of intraoperative ureteroscopy complications using modified Satava classification system World Journal
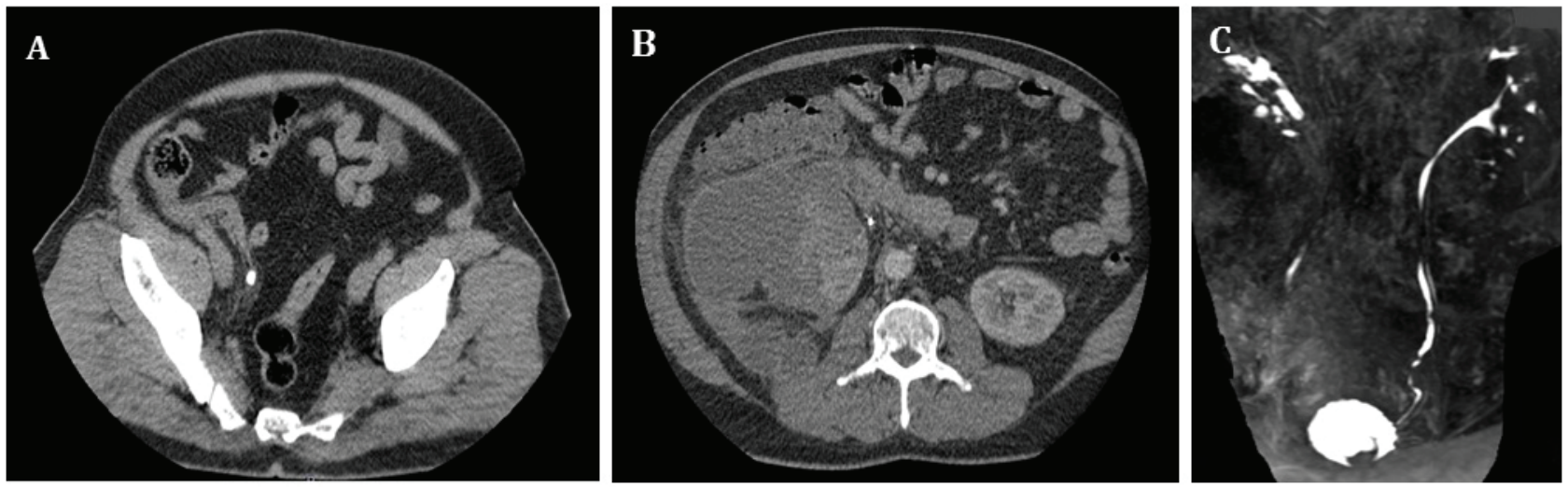

Figure 1. A 10-mm stone in the right distal ureter on computed tomography (CT) scan (A). Abdominal CT scan demonstrated a right perirenal and subcapsular hematoma (B). Perirenal hematoma was mostly resolved without evidence of renal atrophy on MR Urography (1 month later) (C).

\section{DISCUSSION}

Subcapsular or perirenal hematoma after ureteroscopy is an unusual complication and described in literature after flexible ureteroscopy and laser lithotripsy. ${ }^{6-8}$ Although perirenal hematoma is a very rare complication of rigid URS and pneumatic lithotripsy, it should be considered when patients have persistent flank pain and high fever despite antibiotic therapy after URS. Intervention with a flank drain into the hematoma is a safe and effective option to manage the perirenal or subcapsular hematoma and preserve renal function. ${ }^{9,10}$

\section{CONFLICT OF INTEREST}

The authors declare no conflict of interest

\section{REFERENCES}

1. Hofmann R. Ureteroscopy (URS) for ureteric calculi. Urologe A 2006;45:637-46.

2. Wu CF, Shee JJ, Lin WY, et al. Comparison between extracorporeal shock wave lithotripsy and semi rigid ureterorenoscope with holmium:YAG laser litho- of Urology 2014;32:131-6.

5. Bansal U, Sawant A, Dhabalia J. Subcapsular renal hematoma after ureterorenoscopy: an unknown complication of a known procedure. Urol Ann 2010;2:119-21.

6. Watanabe R, Inada K, Azuma K, et al. A case of renal subcapsular hematoma caused by flexible transurethral lithotripsy. Hinyokika Kiyo 2013;59:565-8.

7. Tao W, Cai C, Sun C, et al. Subcapsular renal hematoma after ureteroscopy with holmium: yttriumaluminum-garnet laser lithotripsy. Lasers Med Sci 2015;30:1527-32.

8. Xu L, Li G. Life-threatening subcapsular renal hematoma after flexible ureteroscopic laser lithotripsy: treatment with super selective renal arterial embolization. Urolithiasis 2013; 41:449-51.

9. Gordetsky J, Hislop S, Orloff M, et al. Subcapsular hepatic hematoma with right hepatic vein thrombosis: a complication of shock wave lithotripsy. CUAJ 2008;2:61-3.

10. Bai J, Li C, Wang S, et al. Subcapsular renal haematoma after holmium-aluminum-garnet laser ureterolithotripsy. BJU Int 2011;109:1230-4. 


\title{
Субкапсулярная и периренальная гематома после уретероскопии и пневматической литотрипсии
}

\author{
Мустафа Ресорлу, Мурат Толга Гюлпинар, Гурхан Адам
}

Университет "18 Марта Чанаккале", Чанаккале, Турция

Для корреспонденции:

Мустафа Ресорлу, Университет

"18 Марта Чанаккале",

отделение радиологии, Kepez,

Canakkale, 17100, Turkey

E-mail: mustafaresorlu77@gmail. com

Тел.: +905054548722

Дата получения: 05.12. 2015 г. Дата приемки: 20.06.2016 г.

Дата онлайн публикации: 08.08.2016 г.

Дата публикации: 30.09.2016 г.

Ключевые слова:

субкапсулярная гематома,

камни в уретре, уретероскопия

Цитаты: Ресорлу М., Гюлпинар М.Т., Адам Г. Субкапсулярная и периренальная гематома после уретероскопии и пневматической литотрипсии.

Журнал "Folia Medica"

2016;58(3);215-217,

doi: $10.1515 /$ folmed-2016-0030
Субкапсулярная и периренальная гематома представляет собой необычное усложнение после полужёсткой уретероскопии при дроблении камней в уретре с помощью пневматической литотрипсии. Представляем в качестве примера пациента, у которого появилась большая субкапсулярная и периренальная гематома после проведения уретероскопии из-за наличия камня в правом мочеточнике. 